\title{
MTCP1 wt Allele
}

National Cancer Institute

\section{Source}

National Cancer Institute. MTCP1 wt Allele. NCI Thesaurus. Code C54331.

Human MTCP1 wild-type allele is located in the vicinity of Xq28 and is approximately 86 $\mathrm{kb}$. This allele, which encodes protein $\mathrm{p} 13 \mathrm{MTCP}-1$, may be involved in the regulation of the cell cycle. Aberrant expression of the gene is observed in T-cell leukemias bearing a $t(X ; 14)$ translocation. 